\author{
https://doi.org/10.52449/1857-4114.2020.35-1.04
}

CZU: 796.015:796.38

\title{
STUDY REGARDING THE TACTICAL TRAINING OF JUNIOR TENNIS PLAYERS
}

\author{
Colibaşanu Florin Bogdan1, ORCID: 0000-0002-9240-9967 \\ ${ }^{1}$ Technical University of Civil Engineering, Bucharest, Romania
}

\begin{abstract}
The issue of tactical training in current lawn tennis occupies the attention of coaches and specialists in the field, especially because it is the essential part by which players of equal technical, physical and mental value can tip the balance of victory in their favor. For this reason, in the contemporary training system for athletes, especially in the training process of junior tennis players, more attention is paid to tactical training, to be learned and then improved in proportion to age. In our opinion, the study refers to the search for solutions to improve the tactical training of junior tennis players during training.

Research organization. Starting from the analysis, design, establishment and interpretation of theoretical aspects, the results of the sociological questionnaire conducted on a number of 100 technicians and specialists, of different ages and genders from Romania and the Republic of Moldova, working in children's and junior centers, we can deduce that the issue of tactical training of junior tennis players is topical and of particular concern to those interviewed. Therefore, we consider that, in the training process, the tactical training is conditioned by the theme of the lessons, by the exercises used, by the methodology applied by each specialist, as well as by the individual features of the athletes.

Results. Analyzing the answers of tennis specialists, it was highlighted that notions for learning the tactics of the simple game must be transmitted to athletes from an early age, $75 \%$ of respondents indicated the age under 11 for this, which emphasizes once again the importance of tactics in tennis today. In order to reinforce this idea and to show the special role played by the tactics and strategy approached during a tennis match, all the 100 specialists interviewed answered positively to the question related to this problem, thus, $66 \%$ considered it very effective, the remaining $34 \%$ effective.
\end{abstract}

Keywords: training, tactic, competition, style, exercises, player.

Introduction. The theoretical importance in the field of lawn tennis aims at a new approach in the tactical training of young tennis players, which must contain basic elements of programming combinations, systems and complex means, included in the structure of typical training lessons, which will be based on the knowledge of the age peculiarities and the specifics of the technicaltactical development of the young athletes skills with aptitudes for a certain style of play and which will influence the level of tactical training, which will make the game activity more efficient.

As the authors mention $[1,7,8,17,19$, 27], we are allowed to find that, for a detailed analysis of the aspects regarding the tactical training in sports games, it is necessary to highlight certain concepts related to the role and importance of the components that constitute sports performance. Sports tactics is a part of the general theory of sports training, in which scientific studies are rare and whose theoretical definition is very complex. According to Stefan Achim (2005), 
tactics are "a system of plans, of alternative and distinct actions from each other, which, in order to achieve an objective and respecting some rules, aims at dominating an opponent or a team". In this order of ideas, T.O. Bompa (2003) defines tactical training as follows: "the means by which players assimilate methods and possible ways to prepare and organize offensive and defensive actions, in order to achieve the set goal, to score points, goals, to achieve a certain performance etc. Tactical training can follow generally accepted theories, but it is specific to each sport ".

The study of the specialized literature continues with the current problems and the novelties appeared in the tennis of the last period, from the point of view of the training modeling. The literature in the country and abroad [2, 16, 20, 21, 22, 24] records, but the practice of high-performance play confirms a special fact of modernism in the game of tennis, which refers to the approach of the offensive line in its entirety, both the technique and the tactics of the simple game, regarding the completion of the point. In order to reach the level of high performance, it is necessary for the tennis player to go through a scientific training program, which will exploit its full potential, in order to meet the requirements of the current game. Also, the theoretical instrumentation [13, 14, 18] continued with the factors that condition the tactical training of athletes, the individual peculiarities of athletes at this age, as well as the importance of modeling in tactical training.

Tactical training occupies a very important place in current training in performance tennis, because any shot, any move or any successful or unsuccessful attempt during a point is a consequence of a decision taken in a given situation by a set of circumstances created during a match. The purpose of this periodic plan is to establish guidelines on which to train players.

Following the study conducted on the work of specialists in the field $[3,11,16]$, the important scientific research issue aims at a new approach in the tactical training of young tennis players, which must contain basic elements of programming combinations, systems and complex means, included in the structure of typical training lessons, which will be based on knowledge of age and specificity of technical and tactical development of young athletes skills with aptitudes for a particular style of play and will influence the level of tactical training, which, implicitly, it will streamline the game activity.

The aim of the research is to establish the importance of tactical training in lawn tennis training and its role in increasing the performance of athletes, by questioning, interpreting and studying the opinions of coaches and specialists in the field of field tennis.

Research methods: scientific documentation, study of the specialized bibliography, survey in the form of a questionnaire, interpretation of the questionnaire data.

Organizing and interpreting research results. To determine the significance of tactical training within training, the role of technique in the conduct of an official match and its influence on player performance, between November 2015 and June 2016, we conducted a sociological survey, including 15 questions, attended by 100 coaches and specialists in the field, from Romania and the Republic of Moldova. To make the visual observation better, the data were statistically processed and interpreted graphically through diagrams that highlight the discovered results. 
Table 1. Optimal age for learning simple game tactics

\begin{tabular}{|l|c|c|c|}
\hline \multicolumn{1}{|c|}{ Question } & $\begin{array}{c}\text { Answer } \\
\text { variants }\end{array}$ & Number of answers & $\%$ \\
\hline What do you think is the optimal age to & under 10 years & 57 & 57 \\
start learning simple game tactics? & $10-11$ years & 18 & 18 \\
& $11-12$ years & 6 & 6 \\
& over 12 years & 19 & 19 \\
\hline
\end{tabular}

Regarding the optimal age to start learning tactics in the game of tennis (simple), $57 \%$ of the coaches surveyed chose the option in which simple game tactics are learned under
10 years. Another $18 \%$ of them opted for the learning age between 10-11 years, 6\% between 11-12 years, and 19\% considered the optimal age over 12 years.

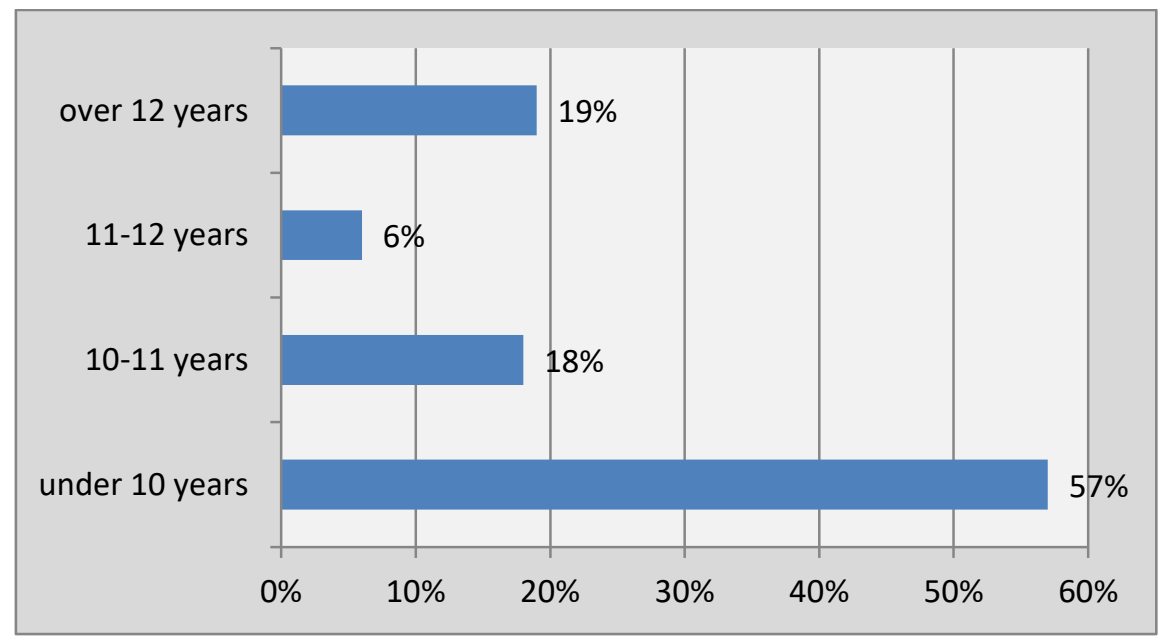

Fig. 1. Structure diagram on the optimal age to start learning simple game tactics

Table 2. Effectiveness of tactics in an official match

\begin{tabular}{|c|c|c|c|}
\hline Question & Answer variants & $\begin{array}{c}\text { Number of } \\
\text { answers }\end{array}$ & $\%$ \\
\hline $\begin{array}{l}\text { How do you assess the } \\
\text { efficiency of tactics in an } \\
\text { official tennis match? }\end{array}$ & $\begin{array}{l}\text { very efficient } \\
\text { effective } \\
\text { ineffective }\end{array}$ & $\begin{array}{l}66 \\
34 \\
-\end{array}$ & $\begin{array}{c}66 \\
34 \\
-\end{array}$ \\
\hline
\end{tabular}

In order to notice the motivation for choosing the research topic and to determine the effectiveness of the tactics in an official match, the majority of coaches surveyed, $66 \%$, considered it very effective and $34 \%$ answered respectively that it is effective.

Another topic of our questionnaire referred to the problem of factors that can change the game tactics chosen and used during an official simple match, and the interviewed coaches had very different opinions, somewhat homogeneous. In the first place was the answer that an important factor would be the tactics of the opponent, 27\%; another important factor follows, the score of the match, with $24 \%$; then the technical training of the opponent (observation of his weaknesses), with $14 \%$ of the answers; $13 \%$ thought that 
their student's fatigue or injury could change the tactics used; and $11 \%$ thought that fatigue, injury of the opponent or his psychological preparation (nervousness) are factors that modify the tactics used to win the match.

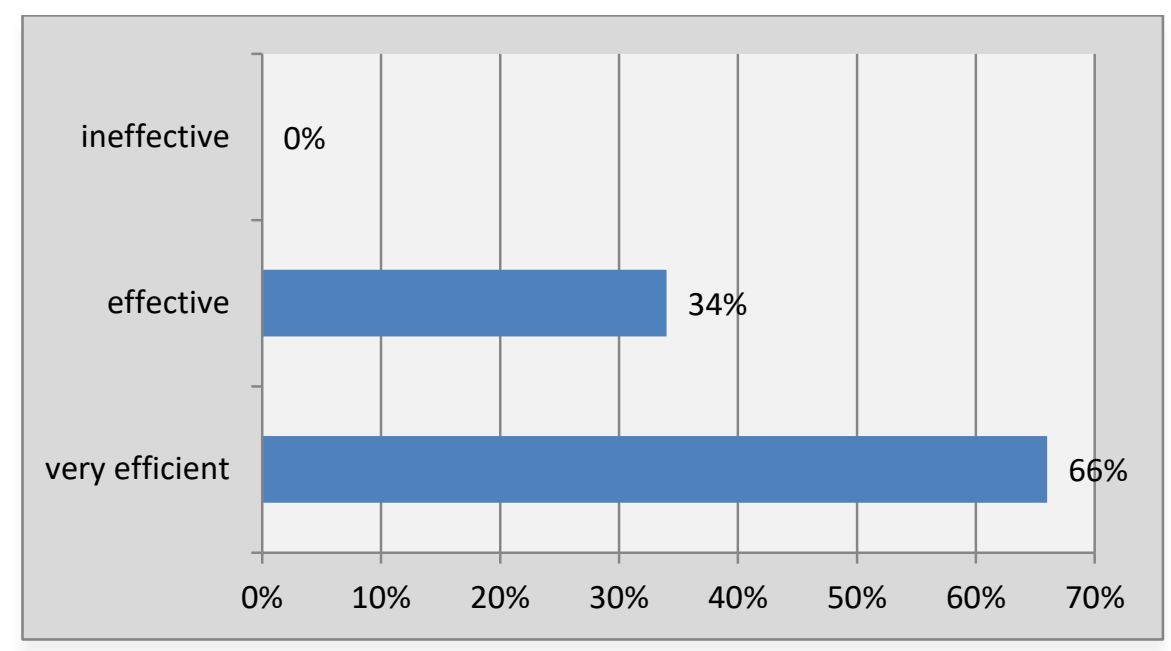

Fig. 2. Structure diagram on the effectiveness of tactics in an official match

Table 3. Factors that can change the tactics used during an official match

\begin{tabular}{|l|c|c|c|}
\hline \multicolumn{1}{|c|}{ Question } & Answer variants & $\begin{array}{c}\text { Number of } \\
\text { answers }\end{array}$ & $\%$ \\
\hline What are the factors that & A (evaluation of the score) & 24 & 24 \\
can change the chosen & B (weather conditions) & 11 & 11 \\
tactics to be used in a & C (fatigue / injury) & 13 & 13 \\
simple match? & D (fatigue / injury of the opponent) & 6 & 6 \\
& E (tactics of the opponent) & 27 & 27 \\
& F (technical training of the opponent) & 14 & 14 \\
& G (physical training of the opponent) & 5 & 5 \\
\hline
\end{tabular}

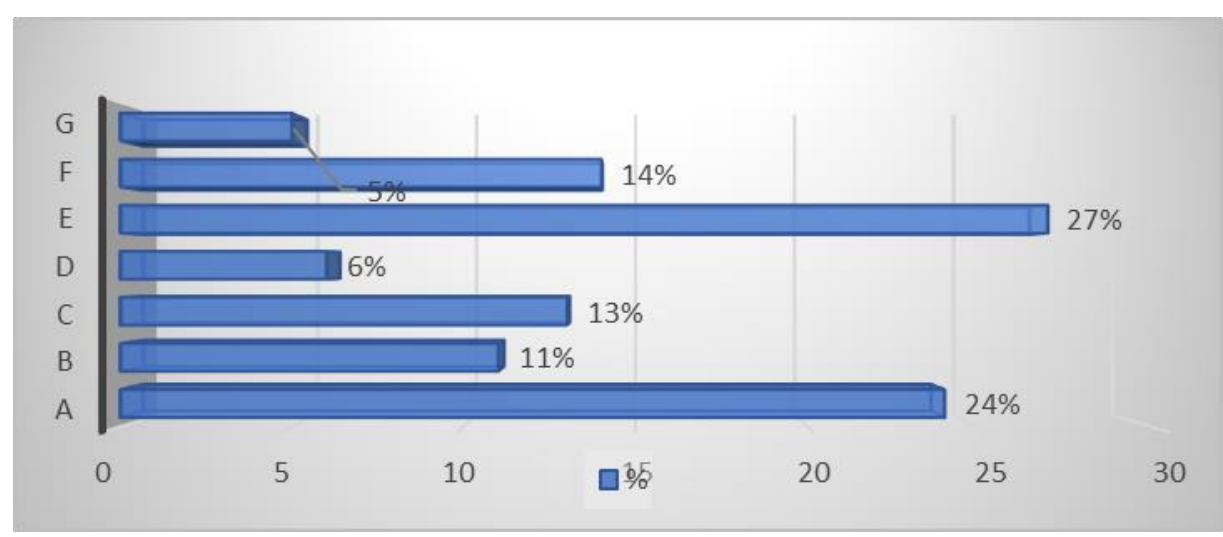

Fig. 3. Structure diagram on the factors that can change the tactics used during an official match 
Table 4. Time for learning tactics in the preparatory period

\begin{tabular}{|l|c|c|c|}
\hline \multicolumn{1}{|c|}{ Question } & Answer variants & $\begin{array}{c}\text { Number of } \\
\text { answers }\end{array}$ & $\%$ \\
\hline What percentage of the daily tennis & $0-10 \%$ & 26 & 26 \\
training do you devote to learning the & $10-20 \%$ & 23 & 23 \\
tactics, in the preparatory stage within the & $20-30 \%$ & 16 & 16 \\
annual cycle? & $30-40 \%$ & 10 & 10 \\
& $40-50 \%$ & 10 & 10 \\
& $50-60 \%$ & 8 & 8 \\
& $60-70 \%$ & 4 & 4 \\
\hline
\end{tabular}

Taking into account the structure and content of sports training in the game of tennis, we tried to highlight the daily training time, given to tactical training in the preparatory stage of the annual training cycle. The answers of the subjects are distributed as follows: $26 \%$ use during this preparatory period a maximum of $10 \%$ during training, $23 \%$ - between $10-20 \%, 16 \%$ of coaches - 20 $30 \%$, then 10 percent opted for $30-40 \%$ and $40-50 \%$ of the time, and the other values are insignificant.

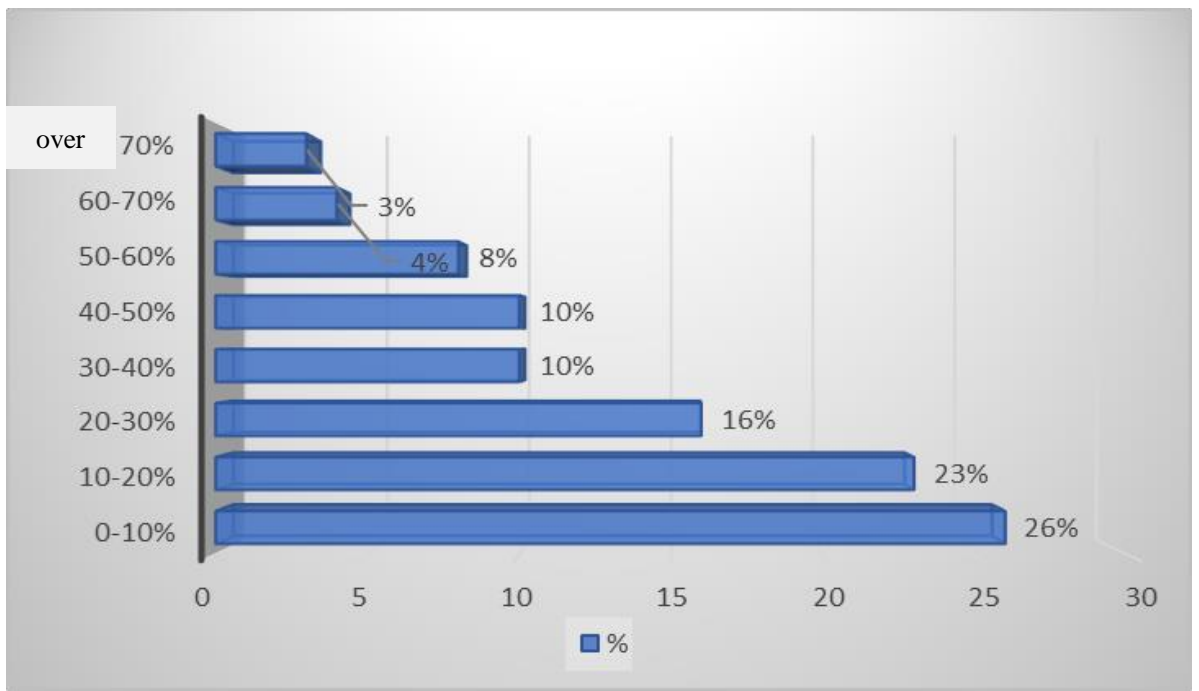

Fig. 4. Structure diagram regarding the time of tactical training in the preparatory period

Table 5. Time for learning tactics in the pre-competition period

\begin{tabular}{|l|c|c|c|}
\hline \multicolumn{1}{|c|}{ Question } & Answer variants & $\begin{array}{c}\text { Number of } \\
\text { answers }\end{array}$ & $\%$ \\
\hline What percentage of the daily tennis & $0-10 \%$ & 3 & 3 \\
training do you devote to tactical & $10-20 \%$ & 13 & 13 \\
learning, in the pre-competition stage & $20-30 \%$ & 37 & 37 \\
of the annual cycle? & $30-40 \%$ & 20 & 20 \\
& $40-50 \%$ & 12 & 12 \\
& $50-60 \%$ & 8 & 8 \\
& $60-70 \%$ & 4 & 4 \\
\hline
\end{tabular}


Another topic of our questionnaire aimed to highlight the time allotted for mastering the tactics of the game of tennis in the precompetition stage of the annual training cycle. According to the researched problem, most coaches, $69 \%$, were of the opinion that the time allocated to tactical training is between $20-50 \%$ of the training hours, less than $20 \%$ only $16 \%$ of the answers, and over $50 \%$ of the time allocated $-15 \%$ of respondents.

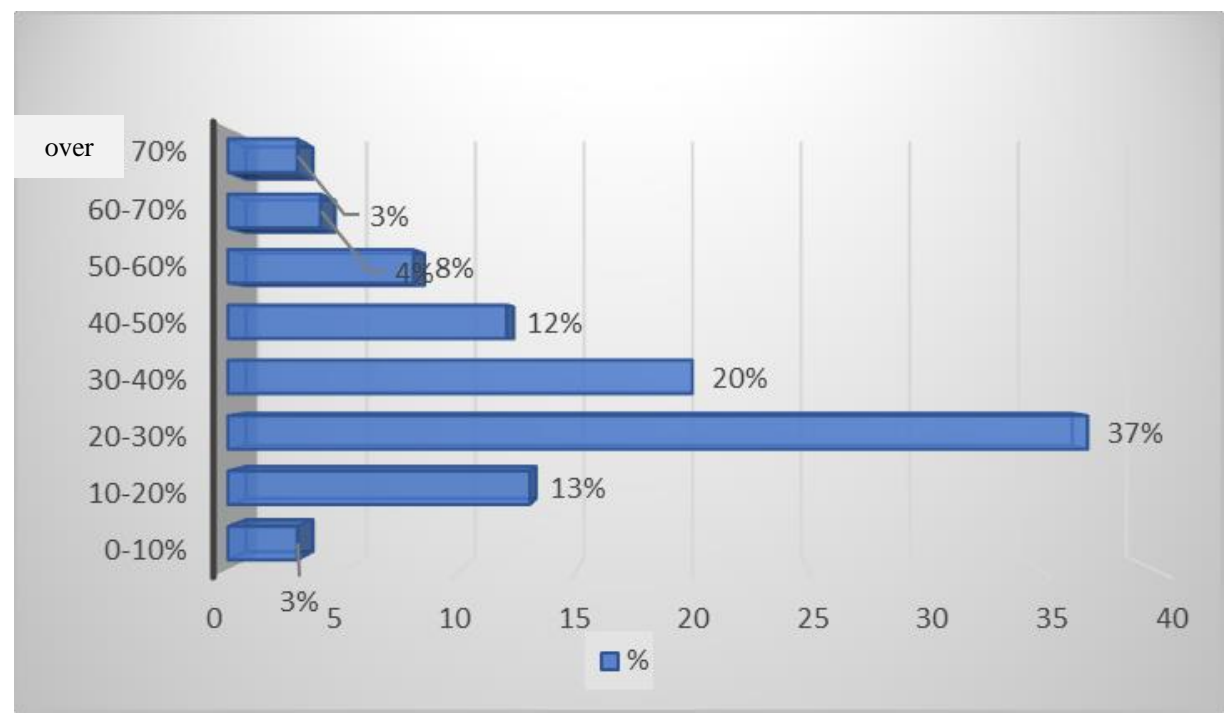

Fig. 5. Structure diagram regarding the time of tactical training in the pre-competition period

Table 6. Time for learning tactics in the competitive period

\begin{tabular}{|l|c|c|c|}
\hline \multicolumn{1}{|c|}{ Question } & Answer variants & $\begin{array}{c}\text { Number of } \\
\text { answers }\end{array}$ & $\%$ \\
\hline What percentage of the daily tennis & $0-10 \%$ & - & - \\
training time do you devote to learning & $10-20 \%$ & - & - \\
tactics, in the competitive stage of the & $20-30 \%$ & 10 & 10 \\
annual cycle? & $30-40 \%$ & 19 & 19 \\
& $40-50 \%$ & 35 & 35 \\
& $50-60 \%$ & 19 & 19 \\
& $60-70 \%$ & 12 & 12 \\
& Over $70 \%$ & 5 & 5 \\
\hline
\end{tabular}

As it was to be expected, on the subject of the percentage given to tactical training in the competitive phase of the annual training cycle, $35 \%$ of coaches surveyed give it between 40 $50 \%$ of training, $19 \%$ - between $50-60 \%$, $12 \%$
- between $60-70 \%$ of the players' training time, which shows the importance of tactical training during this training period. $19 \%$ of coaches consider that $30-40 \%$ of the training time is enough to prepare for the match. 


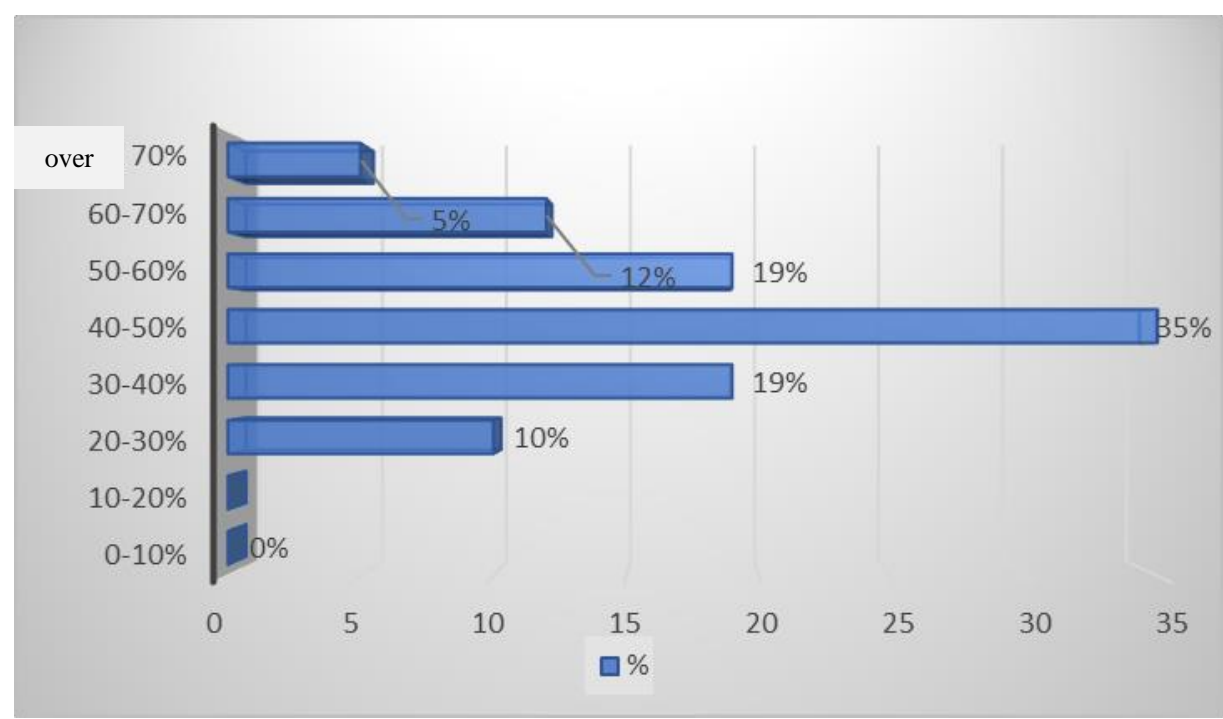

Fig. 6. Structural diagram regarding the time of tactical training during the competition

The analysis of all the answers obtained from the coaches and specialists working in field tennis leads us to the conclusion that the tactical training of young tennis players must be carried out gradually, from easy to hard, from simple to complex, from little to more, from a young age, so that it can be easily assimilated and understood, so that it can be improved with age and with the accumulation of knowledge and skills in training. All this can be done only by correlating the acquisition of tactics with the factors that help and that are indispensable in its learning and improvement. The results of the study allow us to conclude that the physical training of tennis players is a complex process, which extends throughout the career of a tennis player and cannot be missing from the training plan.

\section{References:}

1. Achim Ș. (2005). Planificarea în pregătirea sportivă. București: Renaissance.

2. American sport education program Coaching tennis technical \& tactical skills. Humman Kinetics, 2009.

3. Bollettieri N. (2015). Bollettieri's tennis handbook. Ediția a II. Humman Kinetics.

4. Bompa T. (2002). Teoria şi metodologia antrenamentului sportiv. Bucureşti: Ex-Ponto CNFPA.

5. Bompa T. (2003). Performanța în jocurile sportive. București: Editura Ex-Ponto.

6. Bompa T. (2001). Teoria şi metodologia antrenamentului - periodizarea. București: Editura Tana.

7. Bompa T. (2003). Totul despre pregătirea tinerilor campioni. Constanța: Ex Ponto.

8. Bota I. (1989). Modele de joc şi pregătire. Bucureşti: Editura Sport-Turism.

9. Carp I. (2003). Pregătirea specialiştilor în domeniul culturii fizice pentru activitatea de cercetare ştiinţifică. Chişinău: Valinex SRL.

10. Colibaba-Evuleț D., Bota I. (1998). Jocuri sportive. Teorie şi metodică. Editura Aldin.

11. Crespo M. (1995). Tactical goals for different skill levels: a step by step plan. Coaches Review.

12. Epuran M. (2005). Metodologia cercetării activităților corporale. București: Editura FEST.

13. Epuran M., Stănescu M. (2010). Învățarea motrică - aplicații în activități corporale. București: Discobolul. 
14. Lăzărescu A., Moise G.D. (1986). Tenis. Modelul de joc si metodica generală de pregătire curs. București: ANEFS.

15. Lăzărescu A., Teușdea C. (1999). Tenis - tehnică, tactică, metodică. București: Fundația „România de Mâine”.

16. Moise D., Antonescu D. (2002). Teoria tenisului modern. București: Printnet.

17. Negulescu C. I. (2008). Relația dintre raționalizarea mijloacelor de antrenament și individualizarea pregătirii în jocurile sportive. București: Bren.

18. Niculescu M. (2000). Personalitatea sportivului de performanţăa, factori de personalitate condiţionali ai performanţei sportive de vârf. Bucureşti: Editura Didactică şi Pedagogică.

19. Platonov V.N. (2015). Periodizarea antrenamentului sportiv. București: Discobolul.

20. Schonborn R. (2011). Tenisul, metodologia instruirii. Oradea: Casa.

21. Schonborn R. (1998). Advanced techniques for competitive tennis. Meyer\&Meyer Sport.

22. Segărceanu A. (1998). Tehnică, tactică, metodică. Bucureşti: Guasar.

23. Schultz R. (1993). Să învăţăm tenis de iniţiere la performanţăa. Banat: Editura S.C.Helicon Banat S.A.

24. Stănescu R. (2014). Resurse pentru optimizarea capacității de performanță. București: Bren.

25. Teodorescu S. (2009). Periodizarea și planificarea în sportul de performanță. București: Alpha MDN.

26. Triboi V. (2014). Teoria educației fizice și a sportului. Chișinău: USEFS.

27. Zancu S. (1998). Tenis. Tactica jocului de simplu. Bucureşti: Instant. 